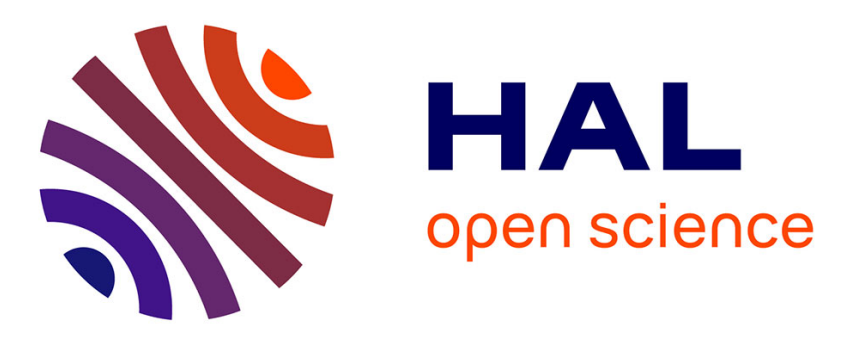

\title{
Analysis of Faults' Effect on the Stability of Surface Lignite Mining Areas Using the Distinct Element Method
}

Marwan Al Heib, Ioannis Zevgolis, Alexandros Theocharis, Nikolaos Koukouzas, Stella Coccia

\section{To cite this version:}

Marwan Al Heib, Ioannis Zevgolis, Alexandros Theocharis, Nikolaos Koukouzas, Stella Coccia. Analysis of Faults' Effect on the Stability of Surface Lignite Mining Areas Using the Distinct Element Method. Geotechnical and Geological Engineering, 2021, 10.1007/s10706-021-01964-z . ineris03337490

\section{HAL Id: ineris-03337490 \\ https://hal-ineris.archives-ouvertes.fr/ineris-03337490}

Submitted on 19 Oct 2021

HAL is a multi-disciplinary open access archive for the deposit and dissemination of scientific research documents, whether they are published or not. The documents may come from teaching and research institutions in France or abroad, or from public or private research centers.
L'archive ouverte pluridisciplinaire HAL, est destinée au dépôt et à la diffusion de documents scientifiques de niveau recherche, publiés ou non, émanant des établissements d'enseignement et de recherche français ou étrangers, des laboratoires publics ou privés. 


\title{
Analysis of faults' effect on the stability of surface lignite mining areas using the distinct element method
}

\author{
Marwan Al Heib ${ }^{1}$, Ioannis E. Zevgolis ${ }^{2}$, Alexandros I. Theocharis ${ }^{3}$, Nikolaos C. \\ Koukouzas ${ }^{3}$, Stella Coccia ${ }^{1}$
}

\author{
${ }^{1}$ Institut National de l'Environnement Industriel et des Risques (Ineris), Ecole des Mines \\ de Nancy, Nancy, France \\ 2 School of Mining and Metallurgical Engineering, National Technical University of \\ Athens, Greece \\ ${ }^{3}$ Chemical Process \& Energy Resources Institute, Centre for Research \& Technology \\ Hellas (CPERI - CERTH), Athens, Greece \\ *corresponding author: izevgolis@metal.ntua.gr
}

\begin{abstract}
Mining operations can drastically affect the stability of nearby areas. A representative case for this has been the Mavropigi mine, a part of an open-pit lignite mining complex in northwestern Greece. Mavropigi is a vast excavation that has reached $150 \mathrm{~m}$ depth and has posed severe challenges and stability issues that caused problems in the area. In 2010, noteworthy surface tension cracks appeared near the excavation, leading to extensive monitoring and countermeasures, while various studies were conducted. The present work aims to revisit the case study of Mavropigi from a different than the previous perspectives. Previous studies were based only on continuum approaches, thus understating or ignoring the effect of discontinuities. Nevertheless, the area has an intense tectonic past and faults that interact with soil movements. In this work, advanced, discontinuous numerical modelling through the distinct element method was used to understand better the role of slope-fault interaction in the case study of Mavropigi and assess the faults' effect on the area's response. The results emphasised the influence of faults on ground movements. The fault's existence increases the impact of the mine operations on the surrounding area significantly and intensifies the possibility of structural damage in nearby constructions. The analysis confirms that the open-pit mine's effect on the surrounding area can be amplified under complex geological conditions, in this case, the presence of faults nearly parallel to the slope inclination.
\end{abstract}

Keywords: coal, open-pit excavations, numerical modelling, discontinuous analysis, discrete element method, damage 


\section{Introduction}

One of the main challenges of mine design is to guarantee the excavations' short- and longterm stability during mining operations, after mine closure and during site reclamation (Bye and Bell 2001; Caudal et al. 2017). Both surface and underground mine operations induce ground movements due to modifying the initial stress conditions; if not appropriately evaluated, they can cause damage to structures and the infrastructure (Riesgo Fernández et al. 2020). Thus, for open-pit mining, slope stability analysis and ground movements quantification are crucial. In Europe, several mines have been affected by slope instability and subsidence due to mining operations, the dewatering during operation, the complexity of the mine itself, and the activities carried out close to the site (Fleurisson 2012; Jambrik 1994; Kavvadas et al. 2013; Kezdi 1979; Svartsjaern 2015; Zevgolis et al. 2019). Notice that the likelihood of instability also depends on the local geology structure (such as particular geomorphologic features, tectonism, and faults).

A case study demonstrating the significant effect of the mining operations on the nearby area is the Mavropigi case. The Mavropigi mine is part of an open-pit lignite mining complex in northwestern Greece. It is a vast excavation that has reached $150 \mathrm{~m}$ depth and has posed severe challenges and stability issues that caused problems in the area. In 2010, noteworthy surface tension cracks appeared near (but not in) the excavation. The phenomenon raised concerns about the pit's and area's stability and the mine's continuing exploitation. Since then, significant monitoring took place, and countermeasures have been applied while various studies were conducted.

This case study is of particular interest as near the open-pit was a village with residential buildings; the village was later relocated. As a result, the surface cracks and the soil settlements damaged some of these buildings and created severe community concerns. The damage of structures due to natural slopes is frequently observed (Del Soldato et al. 
2019), but similar damage is sometimes observed in areas adjacent to open-pit mines (Pitilakis 2008; Zhao et al. 2014).

The present work aims to revisit the case study of Mavropigi from a different than the previous perspectives. Before this paper, the problem was evaluated only through continuum approaches (Kavvadas et al. 2013; Marinos et al. 2015; Steiakakis et al. 2017; Zevgolis et al. 2015), thus understating or ignoring the effect of discontinuities (faults). Nevertheless, it was known, and it has been established, that the area had an intense tectonic past and has faults that could interact with the soil movements.

The presence of faults and the complex geology can amplify any geo-structure instability because they present weak zones (Severin et al. 2010). Typically in the literature, and for the purposes of numerical analysis, faults refer to discontinuities in the rock mass that also reach the ground free surface. Su and Stephansson (1999) studied the effect of faults on modifying the initial soil conditions, particularly stress distribution. They showed that faults significantly modified the stresses and the deformations of the soil. Kattenhorn and Marshall (2006) studied the consequences of tectonic structures on slope stability, and You et al. (2019) studied the effect of three faults on an open-pit mine's slope stability. They concluded that the safety factor of the slope decreased with the introduction of the faults and noticed that higher stress concentration areas were created at the ends of the faults. Soren (2010) demonstrated that for a pit slope of $48^{\circ}$ with an initial safety factor exceeding 1.2, if a fault is present, then the safety factor decreases below 1. Finally, Severin (2017) investigated the stability of deep open-pit mine case studies with faults. He showed the significant impact of fault location, orientation and complexity, on the stress heterogeneity created by the interaction between faults and excavations. These interactions can create zones of high shear strains not typically accounted for stability issues. 
It becomes evident that even one fault in the area close to an open-pit mine can have detrimental effects. In this work, advanced, discontinuous numerical modelling was used to understand better the role of slope-fault interaction in the case study of Mavropigi. Discontinuous modelling was employed through the distinct element method to assess faults' effect on the area's response. Discontinuous numerical modelling has been extensively used to study the stability of open-pit mine excavations with nearby faults and their effect on structures and infrastructure (Eberhardt et al. 2004; Hamman and Coulthard 2007; Rose and Scholz 2009; Severin et al. 2010). The combined effect of openpit and tectonic faults is examined for the Mavropigi excavation and the surrounding area, focusing on the nearby village.

\section{The Mavropigi mine and previous works}

\section{Background}

Greece has been a significant lignite producer in Europe and globally. Lignite accounted for the country's energy supplies as much as 60\% in 2004, 49\% in 2011, and 29\% in 2019 (Eurostat 2020). Greek lignite deposits commonly lie at an average depth of $150-200 \mathrm{~m}$ below surface level and consist of lignite layers alternating with other geomaterials, such as stiff to hard clays and marls (Mikroutsikos et al. 2021). Mining is performed practically exclusively on open-pit mines, and thus, substantial ground-moving processes have been a constant geotechnical challenge (Kavvadas et al. 2020; Zevgolis et al. 2019).

Exploitable lignite deposits are principally located in Western Macedonia, northern Greece. One particular open-pit mine of this area that has posed severe challenges is Mavropigi, located in the Ptolemais basin. Stability issues and large deformations have been observed on several occasions and caused problems in the area, neighbour buildings, and infrastructure. Ptolemais is a North-Northwest to South-Southeast elongated intramontane basin in the Pelagonian geotectonic zone. The basin sediments include Quaternary and Neogene formations (Table 1). The Quaternary layers are mostly 
alluvium deposits consisting primarily of clays and silts. The upper layers of the Neogene formations, which are of interest to the present study, include (a) the upper series, composed of clay - marl clastic sediments, (b) the multi-stratified lignite-bearing series (including an intermediate waste sequence), and (c) the lower series, whose uppermost part consists of marls with lenticular intercalations of marly limestones (Agioutantis et al. 2006; Monopolis et al. 1999). Besides, limestones and schists formations are found towards the southeast slopes of the pit.

Table 1: Basic geologic layers of the Ptolemais area and their characteristics (Agioutantis et al. 2006; Monopolis et al. 1999)

\begin{tabular}{|c|c|c|c|c|}
\hline Period & \multirow{2}{*}{\multicolumn{2}{|c|}{$\begin{array}{c}\text { Characteristics } \\
\text { Alluvium deposits }\end{array}$}} & \multicolumn{2}{|c|}{$\begin{array}{c}\text { Indicative } \\
\text { thickness (m) }\end{array}$} \\
\hline Quaternary & & & $20-80$ & \\
\hline \multirow{5}{*}{ Neogene } & $\begin{array}{l}\text { Upper series } \\
\text { (a) }\end{array}$ & Clay-marl clastic sediments & $100(\mathrm{ma}$ & \\
\hline & \multirow{3}{*}{$\begin{array}{l}\text { Lignite bearing } \\
\text { series }(b)\end{array}$} & Upper multi-stratified lignite sequence & $\begin{array}{c}40 \\
\text { (average) }\end{array}$ & \multirow{3}{*}{135} \\
\hline & & $\begin{array}{c}\text { Intermediate waste sequence } \\
\text { (marls, clays, calcareous mudstones) }\end{array}$ & $\begin{array}{c}15 \\
\text { (average) }\end{array}$ & \\
\hline & & Lower multi-stratified lignite sequence & $\begin{array}{c}80 \\
\text { (average) }\end{array}$ & \\
\hline & $\begin{array}{l}\text { Lower series } \\
\text { (c) }\end{array}$ & $\begin{array}{l}\text { Grey-clayey marls, in places sandy, } \\
\text { with lenticular intercalations of marly } \\
\text { limestones }\end{array}$ & \multicolumn{2}{|l|}{40} \\
\hline
\end{tabular}

The area of Mavropigi belongs to the western border zone of the Ptolemais basin and presents a complicated tectonic structure (Diamantopoulos et al. 2004). It is part of a local graben striking NW-SE intercepted by transverse faults (resulting in the orebody's fragmentation in individual tectonic blocks). An overview of the geologic formations' geotechnical engineering properties based on previous literature is provided in Table 2; Figure 1 presents a simplified cross-section with the geologic layers. The three different lines for each parameter refer to the previous works related to the Mavropigi mine (Kalogirou et al. 2014; Kavvadas et al. 2013; Steiakakis et al. 2017) and will be analysed in the following. 
Mining in Mavropigi has been performed primarily by the continuous mining method; bucket wheel excavators are primarily utilised for the excavation and, secondarily, truck and shovels. The total area of the mining field is about $11 \mathrm{~km}^{2}$. From 2002 to 2012, the accumulated lignite production was about $51.8 \mathrm{Mt}$, and the total excavations had reached 328 bank $\mathrm{Mm}^{3}$. The pit's depth was approximately $150 \mathrm{~m}$, and the pit's mean slope angle ranged between $12^{\circ}$ and $14^{\circ}$. The slopes consisted of 7 or 8 working benches, each $20 \mathrm{~m}$ high by $80 \mathrm{~m}$ wide. The inclination of the bench's face was about $70^{\circ}$.

Table 2: Geotechnical properties of the basic geologic formations

\begin{tabular}{|c|c|c|c|c|c|c|c|c|}
\hline Geology & Materials & $\begin{array}{c}\gamma \\
(\mathrm{kN} / \\
\left.\mathrm{m}^{3}\right)\end{array}$ & $\begin{array}{c}\mathrm{c}^{\prime} \\
(\mathrm{kPa})\end{array}$ & $\begin{array}{l}\varphi^{\prime} \\
\left(^{\circ}\right)\end{array}$ & $\begin{array}{l}\varphi_{\mathrm{r}}^{\prime} \\
\left.{ }^{\circ}\right)\end{array}$ & $\begin{array}{c}\text { E } \\
\text { (MPa } \\
\text { ) }\end{array}$ & $v$ & Reference \\
\hline \multirow[b]{2}{*}{ Quaternary } & \multirow{2}{*}{$\begin{array}{c}\text { Alluvial } \\
\text { deposits } \\
\text { mainly } \\
\text { clays and } \\
\text { some silts }\end{array}$} & 18 & 100 & 20 & - & 100 & 0.3 & $\begin{array}{c}\text { Kalogirou et } \\
\text { al. (2014) }\end{array}$ \\
\hline & & $16-18$ & $5-50$ & $26-30$ & $5-10$ & - & - & $\begin{array}{c}\text { Kavvadas et } \\
\text { al. (2013) }\end{array}$ \\
\hline \multirow{3}{*}{ Neogene } & \multirow{3}{*}{$\begin{array}{c}\text { Marls, } \\
\text { clays, and } \\
\text { lignite } \\
\text { seams }\end{array}$} & 22 & 200 & 33 & - & $\begin{array}{l}350- \\
1000\end{array}$ & 0.3 & $\begin{array}{c}\text { Kalogirou et } \\
\text { al. (2014) }\end{array}$ \\
\hline & & $16-18$ & $50-150$ & $28-35$ & - & - & - & \begin{tabular}{|c|} 
Kavvadas et \\
al. (2013)
\end{tabular} \\
\hline & & $17-18$ & $\begin{array}{l}100- \\
150\end{array}$ & $30-35$ & $8-10$ & - & - & \begin{tabular}{|c|} 
Steiakakis et \\
al. (2017)
\end{tabular} \\
\hline \multirow{2}{*}{ Limestone } & \multirow{2}{*}{$\begin{array}{c}\text { Limestone/ } \\
\text { marble }\end{array}$} & 25 & 17 & 34 & - & 3700 & 0.3 & \begin{tabular}{|c|} 
Kalogirou et \\
al. (2014)
\end{tabular} \\
\hline & & $26-28$ & $\begin{array}{l}400- \\
800 \\
\end{array}$ & $45-50$ & - & - & - & \begin{tabular}{|c|} 
Steiakakis et \\
al. (2017)
\end{tabular} \\
\hline $\begin{array}{l}\text { Schist } \\
\text { (bedrock) }\end{array}$ & Rock like & $22-24$ & $300-400$ & $30-35$ & & & & $\begin{array}{c}\text { Steiakakis et } \\
\text { al. (2017) }\end{array}$ \\
\hline Lignite & & $11-13$ & $\begin{array}{l}150- \\
200\end{array}$ & $34-36$ & - & - & & $\begin{array}{c}\text { Kavvadas et } \\
\text { al. (2013) }\end{array}$ \\
\hline Faults & & - & 50 & 18 & - & - & & \begin{tabular}{|c|}
$\begin{array}{c}\text { Kalogirou et } \\
\text { al. (2014) }\end{array}$ \\
\end{tabular} \\
\hline
\end{tabular}

\section{The case study and previous works}

In 2010, noteworthy surface tension cracks appeared at the crest of the southeast slopes of the excavation, close to the village of Mavropigi. One major crack line near the mine 
was approximately $350 \mathrm{~m}$, and a second one closer to the village was approximately $300 \mathrm{~m}$; several smaller ones appeared in the general area. Simultaneously, horizontal transverse movements varying from a few millimetres to several centimetres were observed at the toe of the lower benches of the excavation. The phenomenon raised concerns about the pit's stability and the excavation's influence on the surrounding area (Kalogirou et al. 2014; Marinos et al. 2015). Large cracks were also observed on the surface (Figure 2). By 2011, persistent horizontal movements at an average of 1-2 cm/day (reaching 4-5 $\mathrm{cm} /$ day during heavy rainfall) were recorded; the volume of the kinematically unstable wedge was estimated at $6 \mathrm{Mm}^{3}$ (Kavvadas et al. 2013). Instrumentation and monitoring were introduced, and countermeasures were applied to ensure the stability of the slopes and the surrounding area.

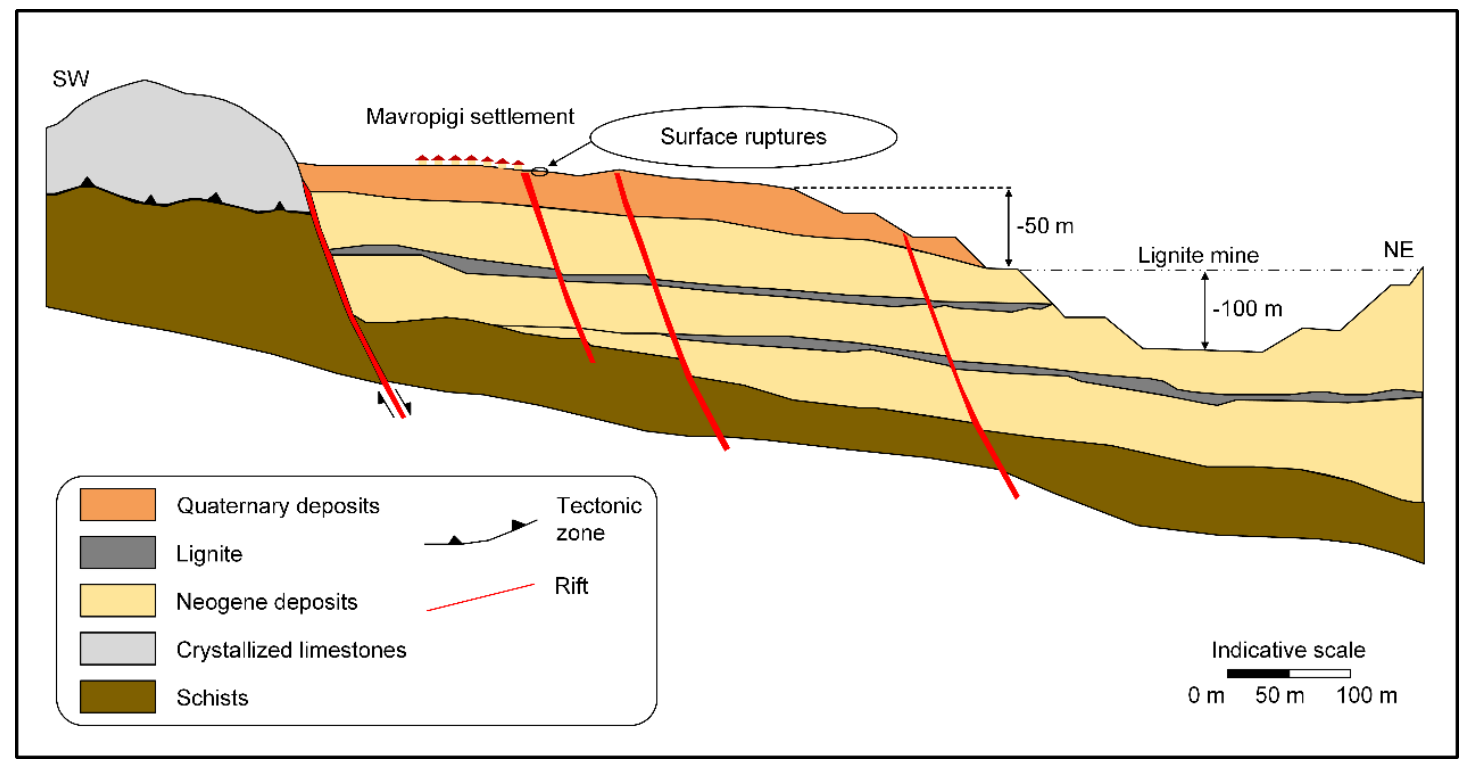

Figure 1: Simplified cross-section of the Mavropigi open coal mine (Kalogirou et al. 2014; Marinos et al. 2015)

Several studies related to the Mavropigi case were published. Kavvadas et al. (2013) presented information from an extensive monitoring campaign and tentatively investigated the stability of the mine's moving southeast slopes. They concluded that 
these slopes were sliding on top of a near-horizontal shear surface with a low residual friction angle (about $7^{\circ}$ ) and argued that it was impossible to model this problem exactly with plain strain limit equilibrium methods. Great emphasis was given in the monitoring program, and a strong dependence of the movement's velocity on precipitation level was detected. Increased velocities of slope movement typically followed days of heavy rainfall.
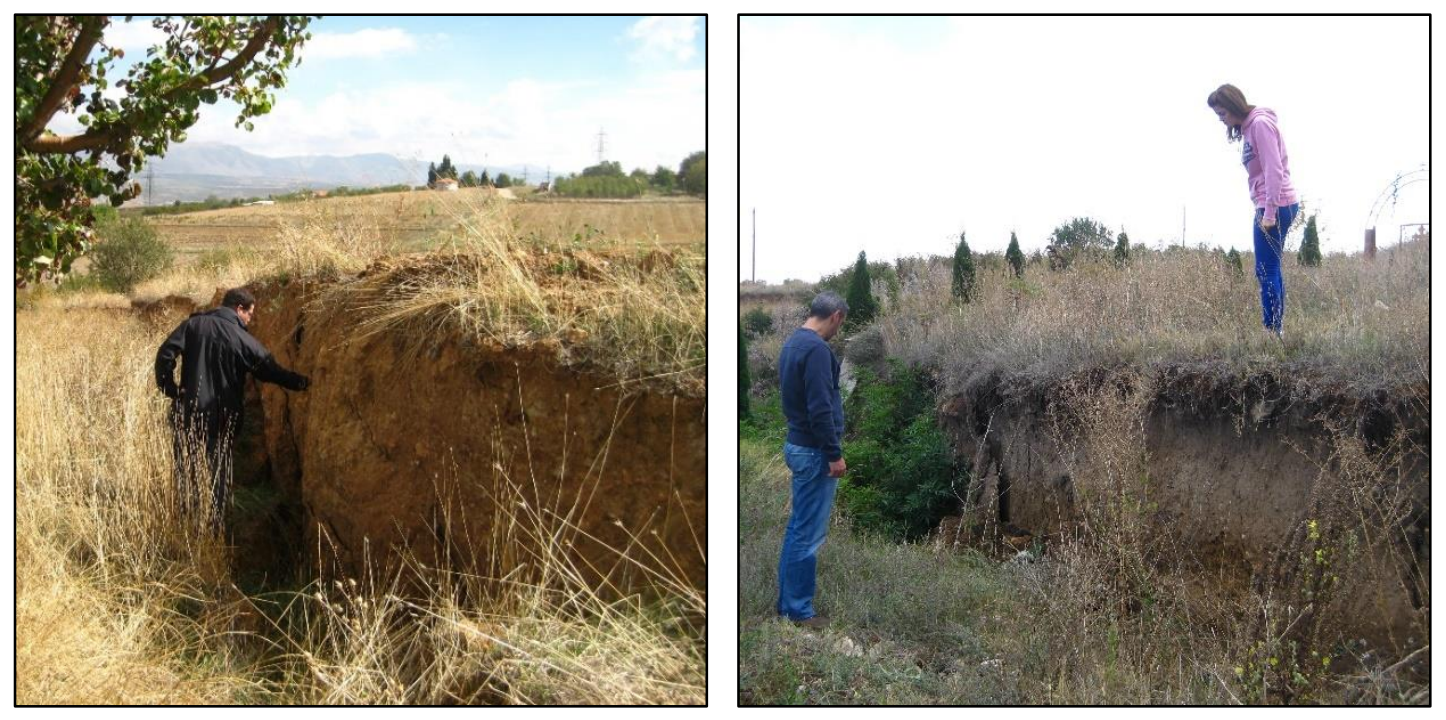

Figure 2: Severe cracks between the mine and the Mavropigi village (October 2013)

Kalogirou et al. (2014) proposed a more comprehensive geological model for the case study (Figure 1). Based on this model, Marinos et al. (2015) performed a finite element analysis to simulate the deformations, the shear and tensile failures, and evaluate the exact mechanism of failure. They concluded that the cracks, the displacements, and the slide failures were connected with the open-pit lignite mine's exploitation. Zevgolis et al. (2015) summarised the most critical parameters related to slope stability and ground subsidence in the Mavropigi mine: the excavation progress's adverse geometry, the geotechnical parameters of the soil formations, the interfaces between layers, and the faults. They also presented a finite element analysis, incorporating the geologic faults as interfaces. 
Finally, Steiakakis et al. (2017) proposed a detailed geological, geotechnical, and kinematic model of the sliding mass and validated it via limit equilibrium back analyses. The sliding mechanism was thoroughly investigated and was identified as a movement of the mine's southeast slopes on a near-horizontal shear zone. This zone included a thin layer of high plasticity clay with a very low residual friction angle.

Several reasons were recognised to be behind the significant movements (Papadaki et al. 2013). Firstly, during mine operations in 2009-2010, the excavation progressed in a nonconventional way due to expropriation limitations. Delays in the land acquisition of a small area in front of the excavation face caused trouble in the production and imposed significant changes in the excavation direction (Roumpos and Papacosta 2013). These changes created an adverse steeply convex geometry in the excavation face with adverse geotechnical effects and decreased the distance to the village more rapidly than planned (Figure 3).
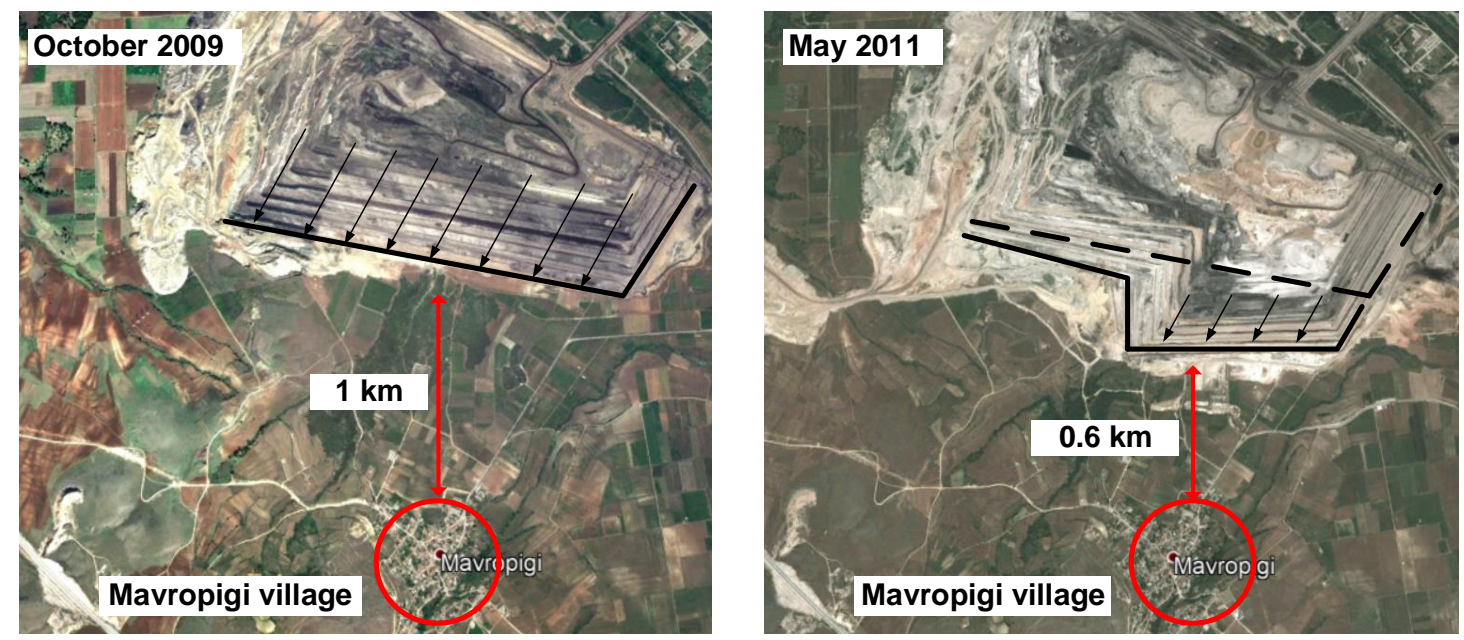

Figure 3: Progress of excavation due to land acquisition issues (a) the excavation with black lines until October 2009 and (b) the excavation progress with black lines until May 2011 and its adverse geometry 
Secondly, the area presented a complicated tectonic structure with steep, inclined faults. More specifically, the mining field is separated by many Northwest-Southeast striking faults into individual fault blocks. The mining field is limited by one or several faults in the village's direction that dip towards the mine.

Finally, the presence of near-horizontal (unfavourably dipping), thin (a few centimetres) high plasticity clay layers was probably critical. These layers are common in the marl lignite intercalations of the Ptolemais mines; they can present very low residual strength and often serve as part of the compound sliding mechanisms of the local mines. (Kavvadas et al. 2020). Theocharis et al. (2021) presented and statistically analysed results from several mines and several samples focusing on the residual strength of weak zones measured by ring shear tests. These zones present a significantly low residual angle of friction, having a mean value of $10^{\circ}$ and a standard deviation of $2.7^{\circ}$. Overall, based on measurements of Greek lignite mines, the weak zone's friction angle can vary from $4.6^{\circ}$ to $15^{\circ}$, i.e. about two standard deviations around the mean value.

\section{Consequences on mining progress and the nearby village}

The tension cracks and settlements had consequences on the progress of the mining operations but also on the nearby village (Figure 3). Initially, the mining plan changed. Detailed monitoring and studies allowed for the continuation of the mining operations on the sliding mass; that was a challenging problem that demanded extra caution (Steiakakis et al. 2017). More specific are the consequences in the nearby village. When the first ground cracks were observed, light damages had already been detected in some buildings. Notice that $85 \%$ of the buildings were residential (with the remaining being either warehouses or abandoned), made from reinforced concrete, bricks/concrete blocks, and stone masonry. Most of the buildings had either only a ground floor or two stories, while a few buildings had a ground floor with a basement. Two inspections (2011 and 2017) from different public bodies took place to detect and record building damages at the local 
scale and identify the location of damages concerning the position and advancement direction of the nearby surface mine. Damages were recorded for each building separately, but a global (comprehensive) assessment of the village as a whole was not performed. The size of the damage was assessed by evaluating the buildings' safety. Overall, $30 \%$ (first inspection) and 70\% (second inspection) of the buildings were evaluated as dangerous or unsafe for use. The difference between the two inspections is of unknown origin, but both evaluations still reflect the village's damage.

\section{Numerical model}

\section{Model parameters}

In this work, the Mavropigi case study is revisited, focusing on faults' effect on stability and ground displacements. For that purpose, the mechanics of discontinuous media rather than continuum mechanics is more appropriate. All the previous studies have used continuum approaches (the limit equilibrium or the finite element method), thus undermining discontinuities' influence (Kavvadas et al. 2013; Marinos et al. 2015; Steiakakis et al. 2017; Zevgolis et al. 2015). The distinct element method was employed herein as implemented in the Universal Distinct Element Code - UDEC (Cundall 1990; Itasca Consulting Group 2018), describing the soil mass as an assemblage of discrete blocks. The discontinuities (faults and interfaces between the geological layers) are treated as boundaries between blocks; thus, large displacements and rotations of blocks can be considered. The discontinuities' elastic behaviour is determined by the normal and shear stiffness $\left(k_{n}\right.$ and $\left.k_{s}\right)$; they are defined as the ratio of normal stress to normal displacement $\left(\mathrm{k}_{\mathrm{n}}\right)$ and shear stress to shear displacement $\left(\mathrm{k}_{\mathrm{s}}\right)$, respectively. The deformable blocks are discretised into finite-difference zones.

Initially, the typical profile of the case study is analysed. Figure 1 presents a simplified cross-section of the Mavropigi open coal mine (Kalogirou et al. 2014; Marinos et al. 2015). This cross-section illustrates the various geological layers, their appearance and the 
existence of faults. In total, four faults roughly parallel to the open pit slope cross the horizontal soil layers. Two of them are specific, while the other two are probable. Similar results could be derived from Steiakakis et al. (2017), but these authors presented a slightly different cross-section from another part of the slopes.

Figure 4 presents the 2D numerical model. The numerical model dimensions were finalised after a trial-and-error investigation to avoid boundary effects, focusing mainly to avoid interactions between faults and boundaries. Boundaries (especially the left boundary of Figure 4) that were not far enough from the faults influenced the results; the right boundary has been chosen based on the fault F1 and the slope's evolution during the excavation of stages 1 and 2 . The final model dimensions were $1250 \mathrm{~m} \times 350 \mathrm{~m}$. The benches of the actual geometry were omitted as they are not crucial for the present investigation that focuses on overall slope analysis and especially on the effects of the faults.

The excavation was within Quaternary and Neogene deposits (see Table 2 and Table 3) and reached a depth of $150 \mathrm{~m}$. For this work, the material properties were assigned according to Kalogirou et al. (2014) and Marinos et al. (2015) and are summarised in Table 3. Most important are the parameters for the two upper layers where the excavation occurs and on which the village is founded, i.e. the Quaternary and Neogenic deposits. These formations consist primarily of clays and silts, while within the Neogene deposits, a mix of marls, clays, and lignite seams was characterised uniformly (see also Table 2).

Schist's formation was practically considered as the underlying bedrock; thus, based on previous literature (Kalogirou et al. 2014; Marinos et al. 2015; Steiakakis et al. 2017), it was assigned a high friction angle and very high cohesion. Notice also that the precise values of the bedrock are not crucial for the present analysis but have to be high enough so that the bedrock is very stiff and with high strength with respect to the other layers. 
Two distinct lignite layers were considered separate from the Neogene deposits, based on the cross-section of Figure 1, and were represented as discontinuities. Finally, the four faults that are the focus of this work were represented as discontinuities and were expected to affect the overall results crucially. The properties of the discontinuities, mainly stiffness and strength for both faults and lignite layers, are practically unknown, and thus, common values were considered. All discontinuities' properties were considered the same to evaluate their influence more balanced and not create significant differences among discontinuities that cross each other. Analysing the effect of the different properties between faults and lignite layers would exceed the aim of this work. The Mohr-Coulomb elastic-perfectly plastic constitutive model was used for all materials.

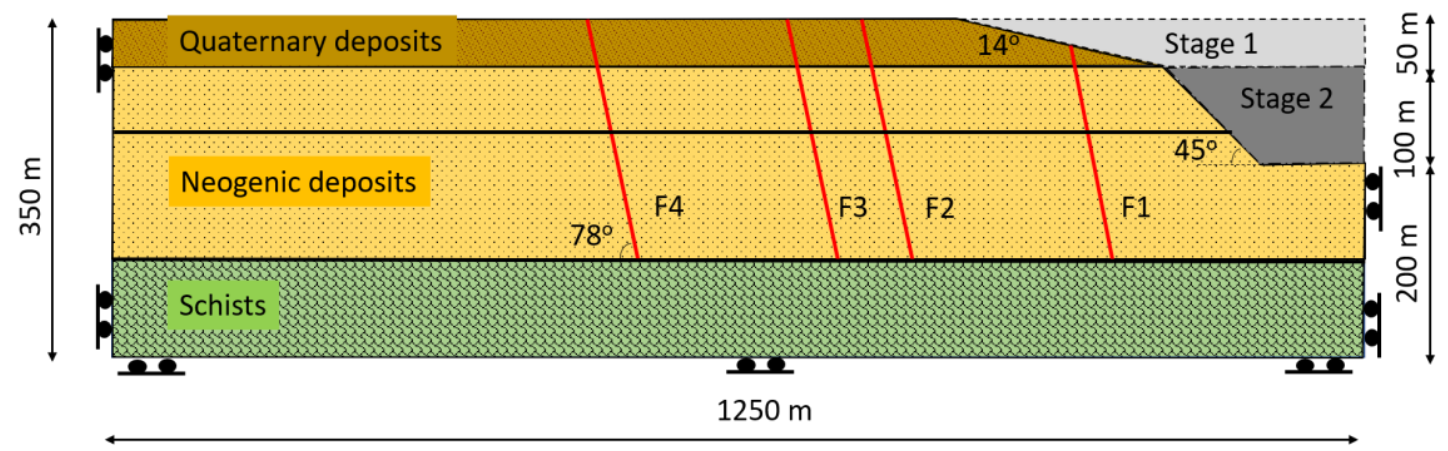

Figure 4: UDEC model, boundary conditions and excavations stages

Geostatic conditions were calculated, and two excavation stages of 50 (stage 1) and 100m (stage 2) were presumed, resulting in a mine 150m deep. Series of parametric studies were performed to overcome the data limitation and study the effects of the various parameters that eventually resulted in eight different models (Table 4). The effect of six parameters was investigated with a focus on the effect of faults on the results. Thus, the analyses are discussed with and without faults, with and without lignite layers, with different lignite layers' inclinations, two faults' stiffness ratios, faults' strength, and different initial earth pressure. 
Initially, model M0 did not consider any faults, while all the other models (M1 to M7) included the four faults of Figure 1. In models M3-M6, the lignite layers were ignored, while for M0, M1, M6, M7, the dip of the lignite layers was $15^{\circ}$ unfavourably to the excavation and for M2 lignite layers were horizontal.

Table 3: Geotechnical properties of the geologic formations of the numerical model

\begin{tabular}{|c|c|c|c|c|c|c|}
\hline Geology & Material & $\begin{array}{c}\gamma \\
\left(\mathrm{kN} / \mathrm{m}^{3}\right)\end{array}$ & $\begin{array}{c}E \\
\text { (MPa) }\end{array}$ & $\mathbf{v}$ & $\begin{array}{c}c^{\prime} \\
(\mathrm{kPa})\end{array}$ & $\varphi^{\prime}\left({ }^{\circ}\right)$ \\
\hline Quaternary & Clay, silts & 18.3 & 100 & 0.3 & 100 & 20 \\
\hline Neogene & $\begin{array}{l}\text { Clay, marls and } \\
\text { lignite seams }\end{array}$ & 22 & 1000 & 0.3 & 250 & 33 \\
\hline Schists & $\begin{array}{l}\text { Limestone, } \\
\text { Marble, Schists }\end{array}$ & 25 & 3750 & 0.25 & 1760 & 34 \\
\hline Interfaces & & $\begin{array}{c}\mathrm{K}_{\mathrm{n}} \\
(\mathrm{MPa} / \mathrm{m})\end{array}$ & $\begin{array}{c}\mathrm{K}_{\mathrm{s}} \\
(\mathrm{MPa} / \mathrm{m})\end{array}$ & & c (kPa) & $\varphi\left({ }^{\circ}\right)$ \\
\hline Lignite/faults & Discontinuities & 66 & 6.6 & & 0 & 18 \\
\hline
\end{tabular}

The effect of the faults' stiffness was considered through the ratio between the normal and shear stiffness $\left(\mathrm{k}_{\mathrm{n}} / \mathrm{k}_{\mathrm{s}}\right)$; two scenarios were analysed for $\mathrm{k}_{\mathrm{n}} / \mathrm{k}_{\mathrm{s}}=10$ and $\mathrm{k}_{\mathrm{n}} / \mathrm{k}_{\mathrm{s}}=100$. The stiffness values are related to the bulk and shear (K and G) modulus of the soil and the feedback of discontinuous studies. Moreover, the effect of the faults' cohesion was investigated; all models had zero cohesion, and only model M5 included a fault cohesion of $50 \mathrm{kPa}$. Finally, the earth pressure coefficient at rest $\left(\mathrm{K}_{\mathrm{o}}\right)$ was varied from 1 (isotropic conditions) to 0.33 (anisotropic conditions). The high $\mathrm{K}_{\mathrm{o}}$ value was chosen as such values have been reported in the literature (Brown and Hoek 1978; Mark and Gadde 2008) but also as an upper limit to intensify its effect and more clearly evaluate its influence. The initial horizontal stresses were typically calculated as $\sigma_{\mathrm{h}}^{\prime}=\mathrm{K}_{\mathrm{o}} \sigma_{\mathrm{v}}^{\prime}$. 
Table 4: Description of the main parameters of the various numerical models

\begin{tabular}{|ccccccc|}
\hline Model & Faults & $\begin{array}{c}\text { Presence } \\
\text { of lignite }\end{array}$ & $\begin{array}{c}\text { Inclination } \\
\text { of lignite } \\
\text { layers }\end{array}$ & $\begin{array}{c}\text { Faults' } \\
\text { stiffness } \\
\text { ratio } \\
\left(\mathbf{k}_{\mathbf{n}} / \mathbf{k}_{\mathbf{s}} \mathbf{)}\right.\end{array}$ & $\begin{array}{c}\text { Faults' } \\
\text { cohesion } \\
\mathbf{( c , ~ k P a )}\end{array}$ & $\begin{array}{c}\text { Coefficient } \\
\text { of earth } \\
\text { pressure } \text { at } \\
\text { rest, } \mathbf{K}_{\mathbf{o}}\end{array}$ \\
\hline M0 & No & Yes & $15^{\circ}$ & - & - & 0.33 \\
\hline M1 & Yes & Yes & $15^{\circ}$ & 100 & 0 & 0.33 \\
\hline M2 & Yes & Yes & $0^{\circ}$ & 100 & 0 & 0.33 \\
\hline M3 & Yes & No & - & 100 & 0 & 0.33 \\
\hline M4 & Yes & No & - & 10 & 0 & 0.33 \\
\hline M5 & Yes & No & - & 10 & 50 & 0.33 \\
\hline M6 & Yes & Yes & $15^{\circ}$ & 100 & 0 & 0.5 \\
\hline M7 & Yes & Yes & $15^{\circ}$ & 100 & 0 & 1 \\
\hline
\end{tabular}

\section{Base numerical model for the evaluation of the faults' effect}

Initially, the two identical base models, one without (M0) and one with faults (M1), are compared. Figure 5 and Figure 6 present the horizontal displacement of the rockmass for the two configurations with and without faults and for the excavation stages at $50 \mathrm{~m}$ (stage 1) and $150 \mathrm{~m}$ (stage 2), respectively. The faults' existence modified the horizontal and vertical displacements, increasing their magnitude. Additionally, the faults' locations are visible on the displacements (horizontal and vertical) due to the discontinuities on their spatial distributions. The maximum horizontal displacement increased by $43 \%$ for stage 1 (from $35 \mathrm{~mm}$ to $50 \mathrm{~mm}$ ) and $25 \%$ for stage 2 (from $80 \mathrm{~mm}$ to $100 \mathrm{~mm}$ ). 

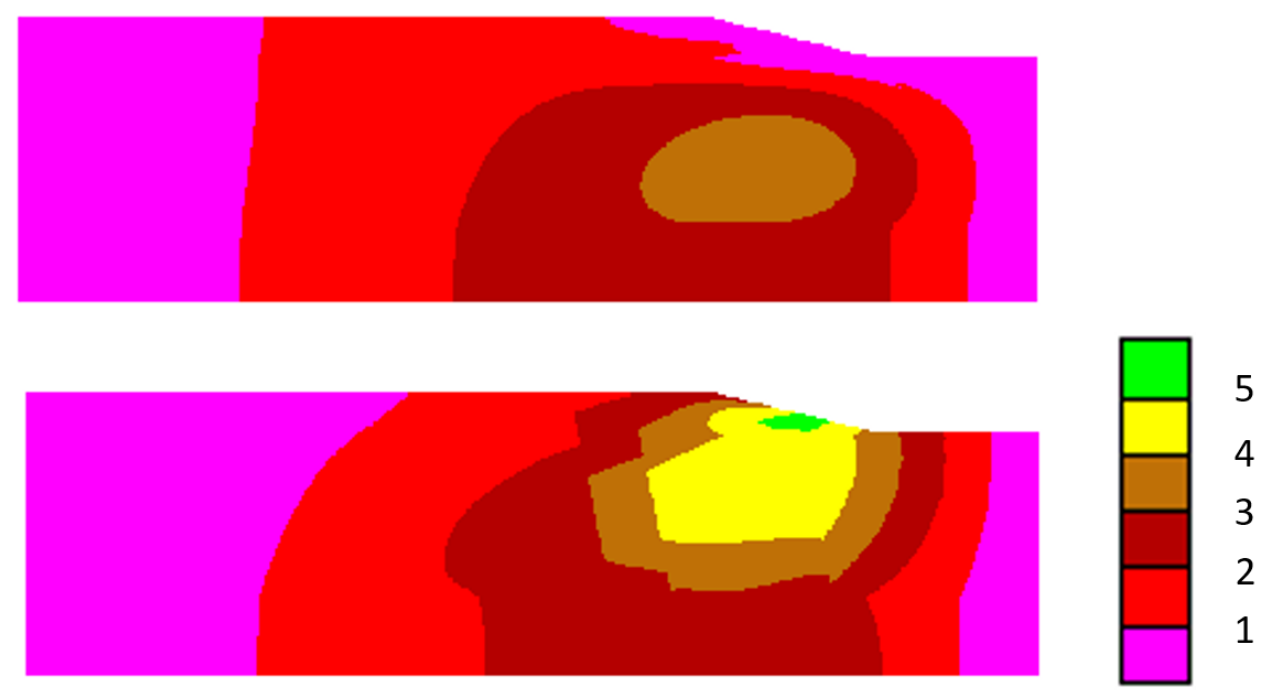

Figure 5: Horizontal displacements (cm) for the configurations (bottom) M1 with and (top) M0 without faults for stage 1
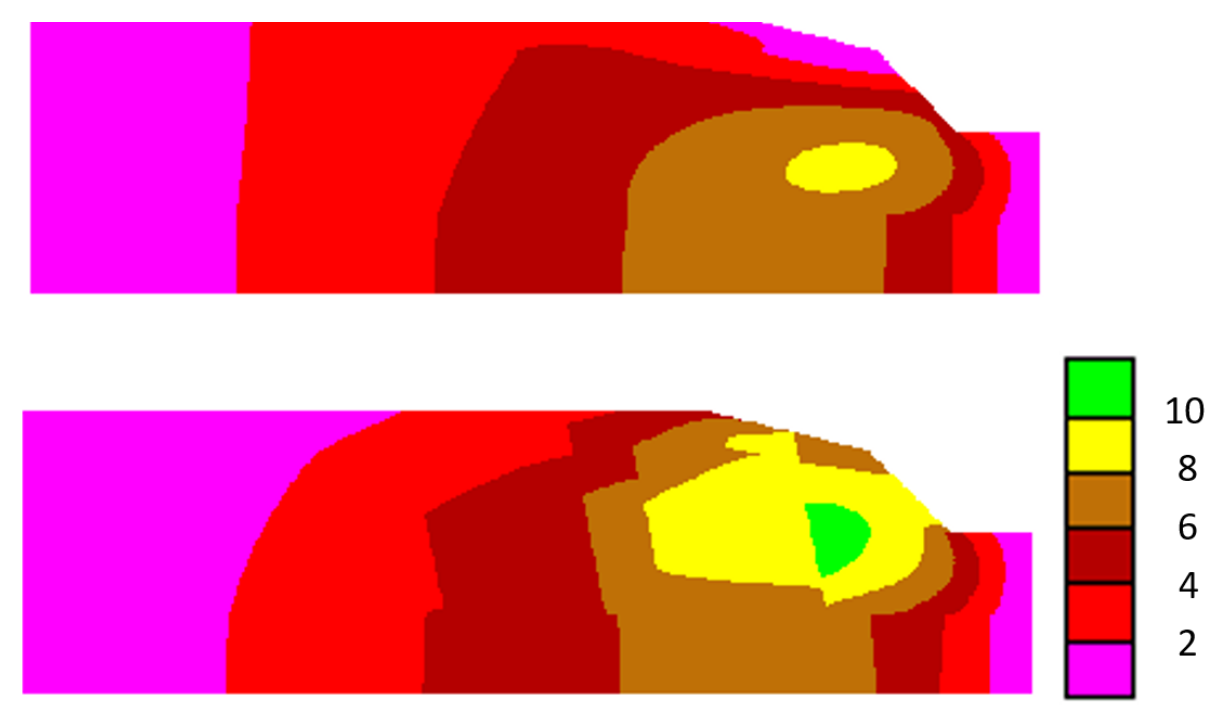

Figure 6: Horizontal displacements (cm) for the configurations (bottom) M1 with and (top) M0 without faults for stage 2

Furthermore, Figure 7 presents the horizontal displacements for stage 2, including faults and highlighting their location and the village's location. Horizontal displacements in the village zone vary between $1 \mathrm{~cm}$ and $4 \mathrm{~cm}$. Similarly, Figure 8 presents the vertical displacements for the same stage. The vertical displacement magnitude varies from $-4 \mathrm{~cm}$ (downwards) to $+6 \mathrm{~cm}$ (upwards), implying differential displacements and open cracks in the area. The three closer-to-the-village faults (F2, F3 and F4) create an apparent 
disruption of the displacements' distribution. The discontinuities of the horizontal displacements are visible on the surface and are consistent with those observed in situ (Marinos et al. 2015; Steiakakis et al. 2017).

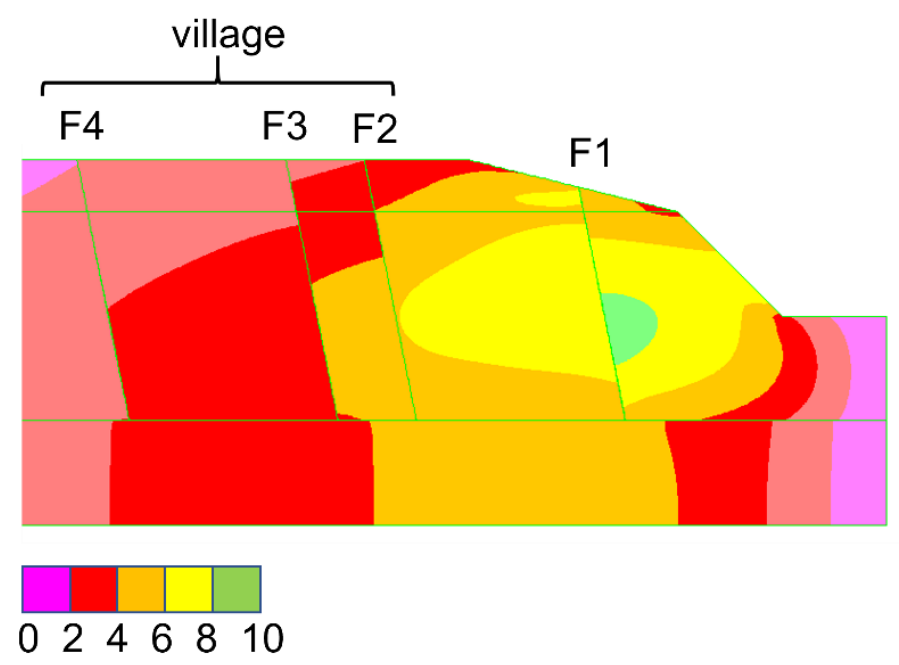

Figure 7: Horizontal displacements (cm) induced by the total excavation (M1) - stage 2 Faults F1 to F4

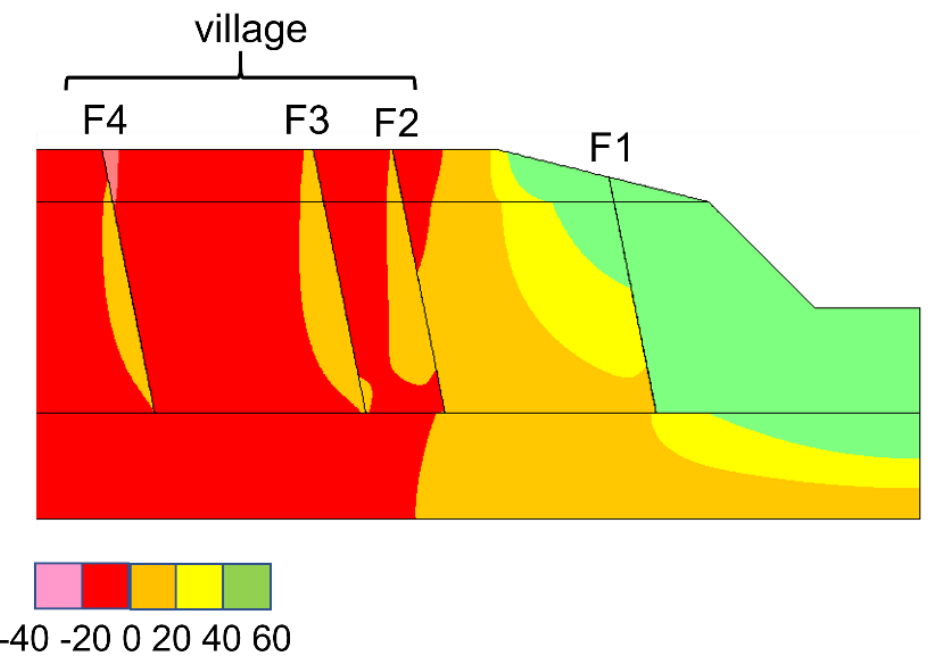

Figure 8: Vertical displacements (cm) induced by the total excavation (M1) - stage 2 Faults F1 to F4

Figure 9 illustrates the plasticity developed within the soil mass for the second excavation stage of model M1, this being a reference model-stage of the analysis. More specifically, 
" $\mathrm{x}$ " (in green) indicates that a plastic state was reached during a former calculation cycle, “*” (in red) indicates that the current stress state is in the plastic range, and "o" (in purple) indicates a current tensile failure. The plastic points (current or past) lie near the slope's edge as stress changes are more significant. This plastic area tentatively corresponds to the unstable zone of the slope. Although few of the past plastic points might be an artifact of the numerical analysis, the trend suggests a plasticity concentration at the bottom, crest, and near the edge of the slope.

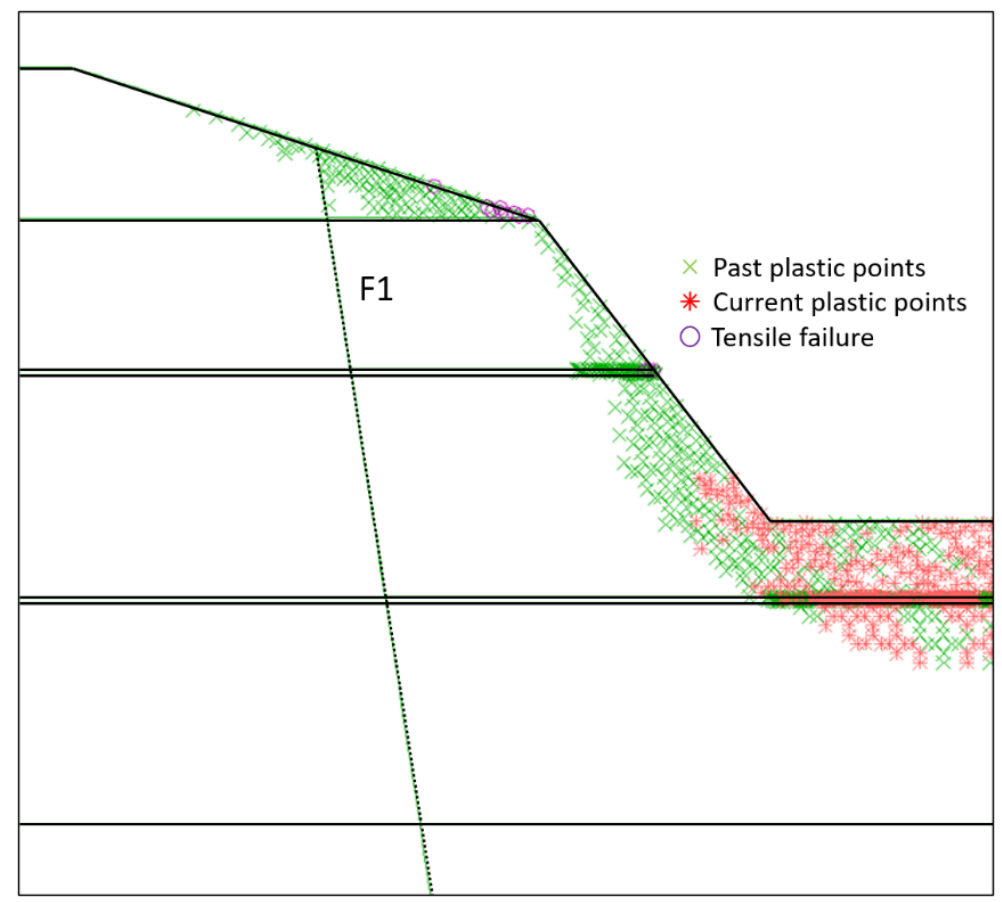

Figure 9: Plastic zones (red and green) and tensile failure (purple) induced by the total mine excavation (M1) - stage 2, F1 (first fault)

Additional information about the response of the faults, particularly their shear and normal forces and displacements developed during the two stages, can be investigated due to the discrete nature of the simulation. Figure 10 presents the shear and normal displacements of the faults and depicts that the open-pit excavation activated the faults by inducing shear and normal displacements on large zones. The shear displacement concerns only the fault that is very close to the excavation (F1), but it has a large maximum 
shear displacement of $161 \mathrm{~mm}$ (Figure $10(\mathrm{~d})$ ). On the contrary, three faults are opened (normal displacements) during the first stage, and all four faults - lying up to 400m away from the excavation - during the second stage. The maximum horizontal opening of the faults equals $37.3 \mathrm{~mm}$ (Figure 10(b)). This "opening displacement" is essential as it possibly caused the open cracks on the surface. Moreover, the intersection between the coal/clay layers and the faults could form a composite surface and trigger a substantial sliding mass. Thus, two potential sliding wedges can be considered: one on the mines' slopes and another in the area surrounding the faults.

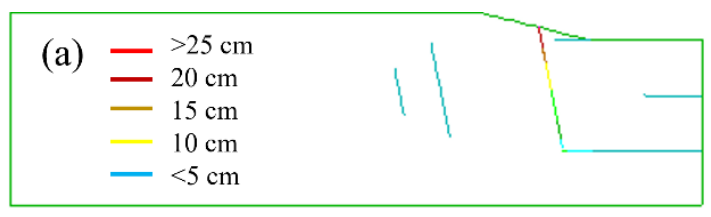

(b)

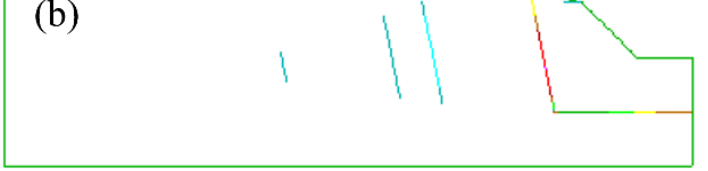

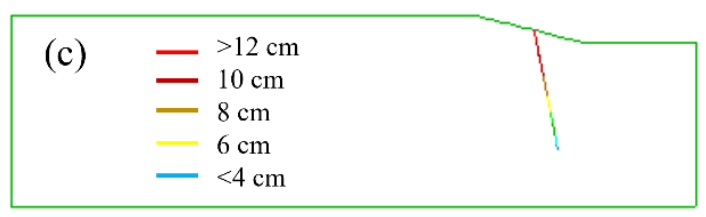

(d)

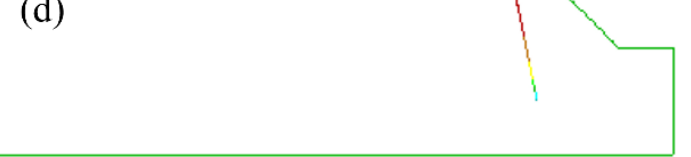

Figure 10: (a) and (b) normal and (c) and (d) shear displacements of the faults at the two stages of the excavation (M1). (a) and (c) are results for stage 1 and (b) and (d) for stage 2 .

Figure 11 presents the profiles of horizontal and vertical displacements at the ground surface for the two excavation stages of model M1. As commonly for excavations, near the mine's slope, an uplift is observed, similarly to the upwards movements of Figure 8. When the excavation occurred, the floor and sides of the excavations move upward, being unloaded; this movement is herein rather intense as a Mohr-Coulomb constitutive law was used, having a constant stiffness and lacking distinction between initial loading and unloading.

The effect of faults is evident and is illustrated as an abrupt change in the displacement curve. As expected, the displacements are larger near the mine and generally diminish 
further away. However, the horizontal displacement slightly increases whenever approaching a fault and then abruptly decreases while the vertical displacement drastically increases due to the fault movement. These rapid changes can produce surface cracks and large differential settlements and are catastrophic for infrastructure and buildings, as were for the village. The differential settlement around the fault F4 is more than $20 \mathrm{~mm}(-20 \mathrm{~mm}$ in Figure 11), and it is large, indicating potential damage to any construction near this area.
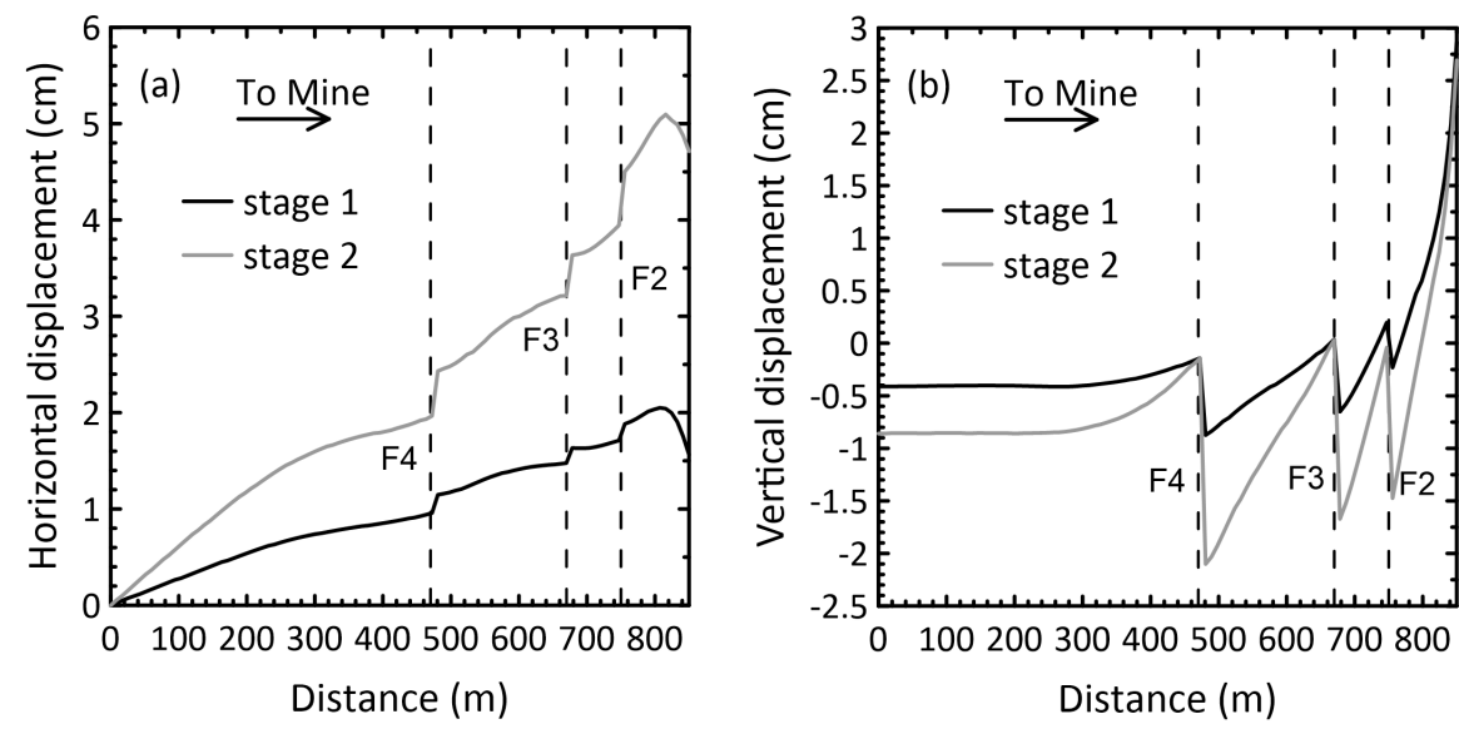

Figure 11: Horizontal (a) and vertical (b) displacements at the ground surface for the two stages of the excavation (M1)

Some doubts could be raised regarding the cohesion of the upper Quaternary layer that appears to be high for clays and silts at that depth. However, notice that such cohesion values have been identified in similar soil materials of lignite mines' excavation. Theocharis et al. (2021) organised and analysed an extensive geotechnical database from several Greek lignite mines; the total mean value of cohesion was $185 \mathrm{kPa}$ and the standard deviation $145 \mathrm{kPa}$. Thus, the cohesion varies a lot and can present large values. 
Nevertheless, a parametric analysis was conducted considering this cohesion's effect on the overall response of the model. Three additional lower cohesion values were evaluated $75 \mathrm{kPa}, 50 \mathrm{kPa}$, and $25 \mathrm{kPa}$. Table 5 summarises some of the main aspects of the model's response to these different cohesions.

Table 5: Effect of Quaternary layer's cohesion on plastic points, maximum vertical and horizontal displacement and maximum fault shear displacement

\begin{tabular}{|c|c|c|c|c|}
\hline $\begin{array}{c}\text { Cohesion } \\
(\mathrm{kPa})\end{array}$ & $\begin{array}{c}\text { Plastic } \\
\text { points }\end{array}$ & $\begin{array}{c}\text { Maximum vertical } \\
\text { displacement }(\mathrm{cm})\end{array}$ & $\begin{array}{c}\text { Maximum } \\
\text { horizontal } \\
\text { displacement }(\mathrm{cm})\end{array}$ & $\begin{array}{c}\text { Maximum fault } \\
\text { shear displacement } \\
(\mathrm{cm})\end{array}$ \\
\hline 100 & 205 & 42.8 & 9.60 & 9.70 \\
\hline 75 & 204 & 42.8 & 9.60 & 9.64 \\
\hline 50 & 248 & 42.8 & 9.62 & 9.62 \\
\hline 25 & 434 & 42.8 & 9.65 & 9.77 \\
\hline
\end{tabular}

Reducing the cohesion of the clay layer corresponds to a significant increase in plastic behaviour, mainly of the clay layer, during the excavation of the open-pit mine (stages 1 and 2). Therefore, more plastic deformations and of higher magnitude are observed on the upper layer. Additionally, at the intersection zones between the faults and the upper layer, the displacement of the faults is accordingly increased. However, the model's maximum vertical and horizontal displacements and the maximum fault shear displacement remain practically the same. Thus, decreasing the upper layer's cohesion amplifies the role of the upper layer, particularly at its intersection with the faults. However, the discussed mechanisms, deformation patterns and overall conclusions on the discontinuities' effect remain practically the same.

\section{Parametric investigation}

The eight different models were compared based on the fundamental factors of the analysis: the density and location of the plastic zones (elements that have reached their yield surface), the maximum displacements of the rockmass (horizontal, vertical and 
shear), and the maximum displacements of the faults (horizontal, vertical and shear). The faults' displacements are critical as they lead to differential movements on the ground surface, affecting the soil's integrity and eventually inducing significant damage to overlying structures. From these factors, four representative ones are illustrated in comparative bars for the two excavation stages. Figure 12 presents the number of the developed plastic zones; Figure 13 and Figure 14 present the maximum vertical and horizontal displacements, respectively, at the excavation slope; Figure 15 presents the shear displacements of the faults.

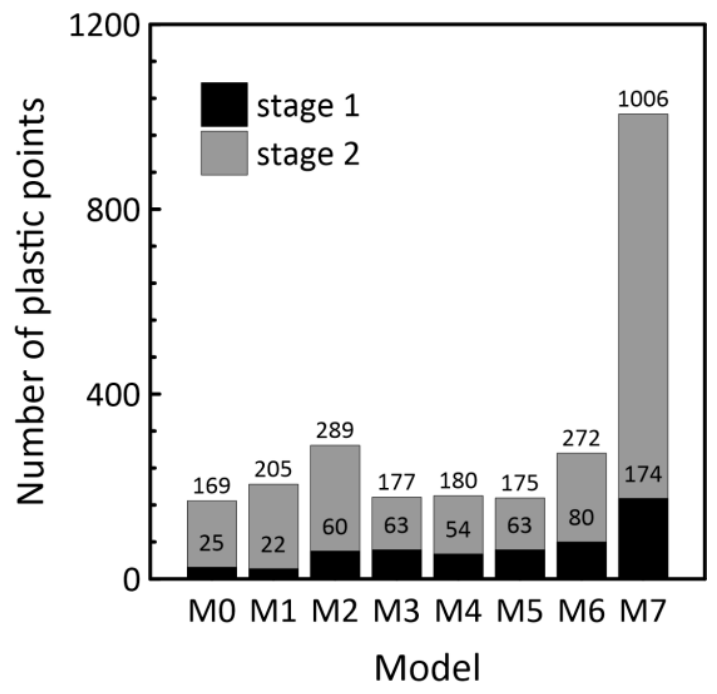

Figure 12: Number of developed plastic points for the eight models (M0 to M7) and the two excavation stages (stage 1 and stage 2 )

The number of plastic zones increased due to the faults when comparing M0 to M1 (from 169 to 205 , a $20 \%$ increase). The maximum vertical and horizontal displacements were located in both models practically at the edge of the excavation slope and were not affected by the faults, as expected. Nevertheless, significant vertical and horizontal displacements were observed in the village area, as previously noted (Figure 7 and Figure 8). The maximum shear displacement of the faults was $9.7 \mathrm{~cm}$, and such a large fault displacement would significantly affect the adjacent areas. 
The role of the lignite layers' presence and inclination was investigated through models M1, M2 and M3. These layers were considered as discontinuities for the numerical analysis with properties same to these of the faults. Model M1 considered a $15^{\circ}$ inclination of the lignite layers, model M2 horizontal lignite layers (zero inclination), and model M3 did not include any lignite layer. No significant effect of the lignite layers was noted on the results. The plastic zones' number vaguely increased with the lignite layer's existence and smaller inclination, mainly due to the interface's effect that offered a way for plasticity to move deeper in the slope (e.g. see Figure 9).

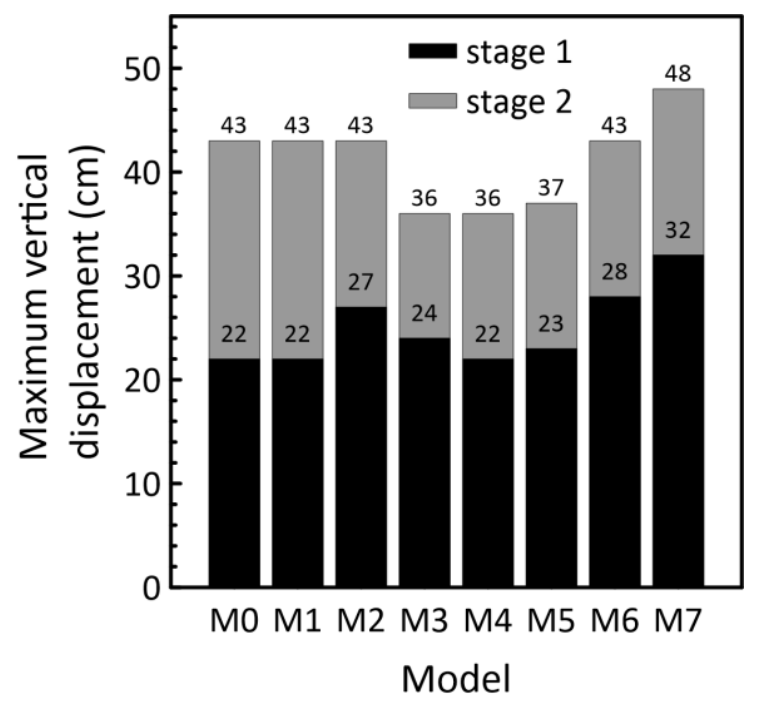

Figure 13: Maximum vertical displacement (cm) for the eight models (M0 to M7) and the two excavation stages (stage 1 and stage 2)

Models M3 and M4 were used to evaluate the effect of the faults' stiffness, described through the ratio of normal to shear stiffness $k_{n} / k_{s}$ as the normal stiffness $k_{n}$ was kept constant; two different ratios were employed $\mathrm{k}_{\mathrm{n}} / \mathrm{k}_{\mathrm{s}}=66 / 0.66=100$ (M3) and $\mathrm{k}_{\mathrm{n}} / \mathrm{k}_{\mathrm{s}}=$ $66 / 6.6=10$ (M4). For the faults, the normal stiffness was kept constant as the shear behaviour of the joints is very variable and difficult to assess as it depends on the filling material and hydraulic conditions (Rode 1991). 
Figure 15 validates this result as the faults' shear displacements were significantly affected by the $\mathrm{k}_{\mathrm{n}} / \mathrm{k}_{\mathrm{s}}$ ratio. The maximum shear displacement after the second excavation stage was almost $9 \mathrm{~cm}$ for $\mathrm{M} 3$ (for lower $\mathrm{k}_{\mathrm{s}}=0.66 \mathrm{MPa} / \mathrm{m}$ ) vs slightly above $3 \mathrm{~cm}$ for $\mathrm{M} 4$ (for higher $\mathrm{k}_{\mathrm{s}}=6.6 \mathrm{MPa} / \mathrm{m}$ ). The number of plastic zones and the maximum vertical and horizontal displacements of the open-pit slopes were not affected by the faults' stiffness. However, the difference in the faults' shear displacements crucially affected the village area's settlements, away from the slope. Additionally, the plastic zones and mass displacements are more related to the local effects of the excavation.

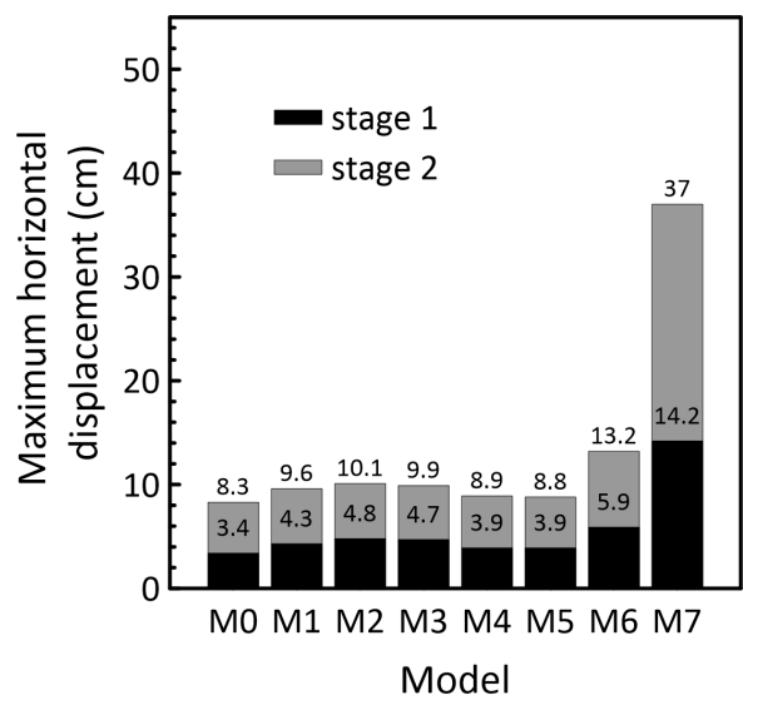

Figure 14. Maximum horizontal displacement for the eight models and the two excavation stages

The role of the faults' cohesion was evaluated through models M4 and M5, with M4 having zero cohesion and M5 $50 \mathrm{kPa}$. As clearly shown in the results, cohesion does not influence the results. The absence of the cohesion effect is due to the mechanism of slope behaviour. Finally, initial horizontal stresses (computed through the $\mathrm{K}_{\mathrm{o}}$ parameter) affect stability and settlements critically. Three different cases were examined, with $K_{0}$ being $0.33,0.5$ (anisotropic conditions) and 1 (isotropic conditions) in models M0, M6 and M7, respectively. An increase in $K_{o}$ significantly affected the response of the excavation. The 
number of developed plastic zones increased with the increase of $K_{0}(205,272$, and 1006, see Figure 12); as the initial horizontal stresses were larger for $K_{0}=1$ when the excavation took place, a greater imbalance was created with larger horizontal stresses "pushing" towards the excavation, leading to a larger plastic area. For the same reason, the maximum horizontal displacement drastically increased with the $K_{0}$ increase $(9.6,13.2$ and $37 \mathrm{~cm}$ ). Faults' shear displacements were affected by the same mechanism and increased with $\mathrm{K}_{0}(9.7$ vs 14.4 vs $20.7 \mathrm{~cm}$ ), while the maximum vertical stress also increases but slightly.

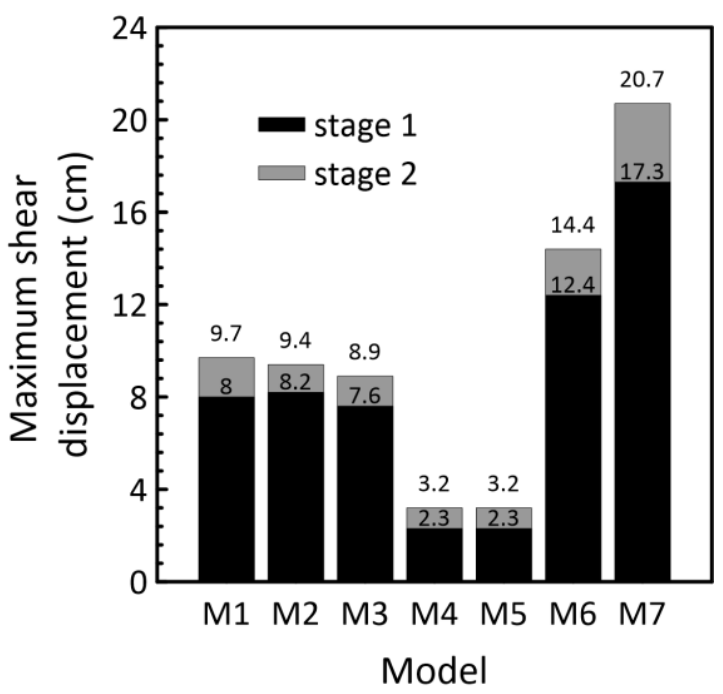

Figure 15. Maximum shear displacement of the faults for the eight models and the two excavation steps

\section{Conclusion}

This work revisited a well-known and established case study of a massive slope instability in a Greek open-pit lignite mine. Mavropigi is a significant lignite mine in northwestern Greece that has posed severe challenges and stability issues and caused large induced deformations and problems. In 2010, noteworthy surface tension cracks appeared near the excavation. The phenomenon raised concerns about the pit's stability and the exploitation of the surrounding area. Since then, significant monitoring has been taking place, and countermeasures have been applied, while various studies analysed the case, 
mainly through back analyses. Before this paper, the problem was evaluated only in a continuum framework, thus understating the discontinuities' effect. In this work, discontinuous modelling was employed through the UDEC software to assess the faults' effect on the area's response.

The results of the 2D numerical modelling highlighted the influence of faults on ground movements. The fault's existence increases the impact of the mine operations on the surrounding area and intensifies the possibility of structural damage in nearby constructions. The analysis confirms that the open-pit mine's effect on the surrounding area can be amplified under complex geological conditions, in this case, the presence of faults parallel to the slope inclination. This effect was evident between the reference model (M0), often used to calculate the safety factor for mine design, and models M1 to M7, which consider the faults. The village zone feels the consequences of the open-pit excavation and the faults' opening and shearing through the horizontal and vertical movements translated into horizontal displacements and differential settlements. Fault movement intensifies the effect of the excavation on the village structures. Especially the effect of shear displacement of the faults depends on their characteristics and the stress state conditions. The lower the shear stiffness of the faults and the higher the horizontal stresses, the more significant the shear displacement becomes.

Plastic deformations develop primarily at the edge of the slope and the base of the excavation. The number of plastic zones increases significantly after the second stage of the excavation. However, as plastic zones are mainly close to the slope, their number does not vary much with fault and lignite layers' parameters. Only when the horizontal stress coefficient increases, then the number of plastic zones drastically increases too. Similarly, maximum vertical and horizontal displacement always appeared near the edge of the open-pit slope and were not affected by the presence of faults. Again, the maximum 
horizontal displacement is higher for the higher horizontal stress coefficient, but this effect is less important for the maximum vertical displacement.

The Mavropigi case study shows that buildings' damage depends on their position relative to the mine excavation and should consider any complex geological conditions. In any case, the size of the influence zone depends on local faults and discontinuities. The aggravating effects to be generally considered are mine operation and faults, soft layers and dewatering. The mine design should commonly consider the slope stability and the impact of natural and anthropic factors on buildings near the mine.

\section{Acknowledgments}

This project has received funding from the European Union's Research Fund for Coal and Steel under the projects "SLOPES - Smarter Lignite Open Pit Engineering Solutions" Grant agreement No. RFCR-CT-2015-00001 and "RAFF - Risk assessment of final pits during flooding slopes" Grant agreement No. 847299, and by the French Ministry for Ecology, Sustainable Development and Spatial Planning. Financial assistance by the above authorities is greatly appreciated.

\section{$\underline{\text { References }}$}

Agioutantis Z, Steiakakis E, Kalogirou I, Kourkoutis S (2006) An investigation of the stability and deformations of a deep open pit lignite mine using finite elements analysis. Mining Information and Analytical Bulletin 10:123-130

Brown ET, Hoek E (1978) Trends in relationships between measured in-situ stresses and depth. International Journal of Rock Mechanics and Mining Sciences \& Geomechanics Abstracts 15:211-215. https://doi.org/10.1016/0148-9062(78)91227-5

Bye AR, Bell FG (2001) Stability assessment and slope design at Sandsloot open pit, South Africa. International Journal of Rock Mechanics and Mining Sciences 38:449-466. https://doi.org/10.1016/S1365-1609(01)00014-4

Caudal P, Grenon M, Turmel D, Locat J (2017) Analysis of a Large Rock Slope Failure on the East Wall of the LAB Chrysotile Mine in Canada: LiDAR Monitoring and Displacement Analyses. Rock Mechanics and Rock Engineering 50:807-824. https://10.1007/s00603-016-1145-3

Cundall PA (1990) Numerical modelling of jointed and faulted rock. In: Rossmantith HP (ed) Mechanics of jointed and faulted rock. Balkema, Rotterdam,

Del Soldato M et al. (2019) Assessment of landslide-induced damage to structures: the Agnone landslide case study (southern Italy). Bulletin of Engineering Geology and the Environment 78:2387-2408. https://10.1007/s10064-018-1303-9 
Diamantopoulos A, Dimitrakopoulos D, Fountoulis I (2004) Quaternary Deformation of the Mavropigi Lignite Field (Western Margin of Ptolemais - Kozani Graben, NW Macedonia, Greece). Bulletin of the Geological Society of Greece 36:310-319

Eberhardt E, Stead D, Coggan JS (2004) Numerical analysis of initiation and progressive failure in natural rock slopes - the 1991 Randa rockslide. International Journal of Rock Mechanics and Mining Sciences 41:69-87. https://doi.org/10.1016/S13651609(03)00076-5

Eurostat (2020) Energy mix for EU electricity generation for 2017.

Fleurisson J-A (2012) Slope Design and Implementation in Open Pit Mines: Geological and Geomechanical Approach. Procedia Engineering 46:27-38. https://doi.org/10.1016/j.proeng.2012.09.442

Hamman E, Coulthard M (2007) Developing a numerical model for a deep open pit. In: International Symposium on Rock Slope Stability in Open Pit Mining and Civil Engineering, pp 225-237

Itasca Consulting Group (2018) UDEC — Universal Distinct Element Code, Ver. 7.0. . Minneapolis: Itasca.

Jambrik R (1994) Environmental Effects of Dewatered Open Pit Mines. In: 5th International Mine Congress,

Kalogirou EE, Tsapanos TM, Karakostas VG, Marinos VP, Chatzipetros A (2014) Ground fissures in the area of Mavropigi Village (N. Greece): Seismotectonics or mining activity? Acta Geophysica 62:1387-1412. https://10.2478/s11600-014-0241-6

Kattenhorn SA, Marshall ST (2006) Fault-induced perturbed stress fields and associated tensile and compressive deformation at fault tips in the ice shell of Europa: implications for fault mechanics. Journal of Structural Geology 28:2204-2221. https://doi.org/10.1016/j.jsg.2005.11.010

Kavvadas M, Agioutantis Z, Schilizzi P, Steiakakis C (2013) Stability and movements of openpit lignite mines in Northern Greece. In: 18th International Conference on Soil Mechanics and Geotechnical Engineering, pp 2193-2196

Kavvadas M, Roumpos C, Schilizzi P (2020) Stability of Deep Excavation Slopes in Continuous Surface Lignite Mining Systems. Geotechnical and Geological Engineering 38:791-812. https://10.1007/s10706-019-01066-X

Kezdi A (1979) Surface subsidence due to open pit coal mining. Periodica Polytechnica Civil Engineering 23:3-19

Marinos V, Tsapanos T, Pavlidis S, Tsourlos P, Chatzipetros A, Voudouris K (2015) Large Induced Displacements and Slides Around an Open Pit Lignite Mine, Ptolemais Basin, Northern Greece. In: Engineering Geology for Society and Territory-Volume 2. Springer, pp 311-315

Mark C, Gadde M Global trends in coal mine horizontal stress measurements. In: 27th International Conference of Ground Control in Mining, Morgantown, 29-31 July 2008. pp 319-331

Mikroutsikos A, Theocharis AI, Koukouzas NC, Zevgolis IE (2021) Slope stability of deep surface coal mines in the presence of a weak zone. Geomechanics and Geophysics for Geo-Energy and Geo-Resources 7 (66). https://doi.org/10.1007/s40948-021-00265-2

Monopolis D, Steiakakis E, Agioutantis E, Kavouridis C (1999) Geotechnical Investigation at lignite mines. Mineral Resources Engineering 8:405-418

Papadaki E, Tripolitsiotis A, Steiakakis C, Agioutantis Z, Mertikas S, Partsinevelos P, Schilizzi $P$ (2013) Land movement monitoring at the Mavropigi lignite mine using spaceborne D-InSAR. In: First International Conference on Remote Sensing and Geoinformation of the Environment, $\mathrm{p}$ 87951A

Pitilakis K (2008) Vulnerability (physical) assessment of buildings and infrastructures. Intensive Course in Quantitive Landslide Risk Assessment and Risk Management Lecture

Riesgo Fernández P, Rodríguez Granda G, Krzemień A, García Cortés S, Fidalgo Valverde G (2020) Subsidence versus natural landslides when dealing with property damage 
liabilities in underground coal mines. International Journal of Rock Mechanics and Mining Sciences 126:104175. https://doi.org/10.1016/j.ijrmms.2019.104175

Rode N (1991) Caractérisation et modélisation des massifs rocheux fracturés en blocs. Institut National Polytechnique de Lorraine

Rose N, Scholz M (2009) Analysis of complex deformation behaviour in large open pit mine slopes using the Universal Distinct Element Code (UDEC). In: Slope Stability 2009 International Symposium on Rock Slope Stability in Open Pit Mining and Civil Engineering,

Roumpos C, Papacosta E Strategic mine planning of surface mining projects incorporating sustainability concepts. In: 6th International Conference on Sustainable Development in the Minerals Industry, Milos Island, Greece, 2013. pp 645-651

Severin J (2017) Impact of faults and fault damage zones on large open pit slopes. University of British Columbia, Canada

Severin J, Eberhardt E, Woo K (2010) Influence of major fault zones on 3-D ground deformations caused by open pit - block cave interactions. In: Second International Symposium on Block and Sublevel Caving,

Soren M (2010) Effect of faults on the stability of slopes in open cast mines (BSc Thesis). National Institute of Technology. Rourkela

Steiakakis C, Agioutantis Z, Apostolou E, Papavgeri G (2017) Mining in a Landslide- Is It Possible? Geotechnical Investigation and Analysis. In: Geotechnical Frontiers 2017 GSP 278, pp 264-274

Su S, Stephansson O (1999) Effect of a fault on in situ stresses studied by the distinct element method. International Journal of Rock Mechanics and Mining Sciences 36:1051-1056. https://doi.org/10.1016/S1365-1609(99)00119-7

Svartsjaern M (2015) Predominant failure mechanisms at the Kiirunavaara mine footwall (Doctoral Thesis). Luleå University of Technology

Theocharis AI, Zevgolis IE, Koukouzas NC (2021) A comprehensive geotechnical characterization of overburden material from lignite mine excavations. Geomechanics and Geophysics for Geo-energy and Geo-resources 7:30. https://doi.org/10.1007/s40948-021-00230-z

You G, Jaggi N, Al Mandalawi M, Dowling K, Dahlhaus P (2019) Effect of Faults on Stability of Partially Saturated Rock Slope. In: International Conference on Geomechanics, Geoenergy and Geo-resources IC3G 2018,

Zevgolis IE, Deliveris AV, Koukouzas NC (2019) Slope failure incidents and other stability concerns in surface lignite mines in Greece. Journal of Sustainable Mining 18:182-197. https://doi.org/10.1016/j.jsm.2019.07.001

Zevgolis IE, Koukouzas N, Schilizzi P (2015) Deformations and stability of a surface lignite mine-a challenging case study. In: Proceedings, AIMS 2015, 5th International Symposium on Mineral Resources and Mine Development,

Zhao H, Ma F, Zhang Y, Guo J (2014) Monitoring and assessment of mining subsidence in a metal mine in China. Environmental Engineering \& Management Journal (EEMJ) 13:3015-3024 